\title{
Needle longevity, shoot growth and branching frequency in relation to site fertility and within-canopy light conditions in Pinus sylvestris
}

\author{
Ülo Niinemets ${ }^{a *}$ and Aljona Lukjanovab \\ ${ }^{a}$ Department of Plant Physiology, Institute of Molecular and Cell Biology, University of Tartu, Riia 23, 51011 Tartu, Estonia \\ ${ }^{b}$ Department of Ecophysiology, Institute of Ecology, Tallinn University of Educational Sciences, Kevade 2, Tallinn 10137, Estonia
}

(Received 10 September 2001; accepted 25 June 2002)

\begin{abstract}
Changes in needle morphology, average needle age, shoot length growth, and branching frequency in response to seasonal average integrated quantum flux density $\left(Q_{\text {int }}\right)$ were investigated in Pinus sylvestris L. in a fertile site (old-field) and an infertile site (raised bog). In the fertile site, the trees were 30 years old with a dominant height of 17-21 m, and with average \pm SD nitrogen content (\% of dry mass) of $1.53 \pm 0.11$ in the current-year needles. In the infertile site, 50 to 100 -yr-old trees were $1-2 \mathrm{~m}$ tall, and needle $\mathrm{N}$ content was $0.86 \pm 0.12 \%$. Relationships between the variables were studied using linear correlation and regression analyses. With increasing irradiance, shoot length $\left(L_{\mathrm{s}}\right)$ and shoot bifurcation ratio $\left(R_{\mathrm{b}}\right.$, the number of current-year shoots per number of shoots formed in the previous year) increased in the fertile site, but not in the infertile site. Despite greater branching frequency, apical control was enhanced at higher irradiance in the fertile site. The shoot length distributions became more peaked (positive kurtosis) and biased towards lower values of $L_{\mathrm{s}}$ (positive skewness) with increasing $Q_{\text {int }}$ in this stand. The shoot distributions were essentially normal in the infertile site. Large values of $R_{\mathrm{b}}$ combined with the skewed distributions of shoot length resulted in conical crowns in the fertile site. In contrast, lower bifurcation ratio, normal shoot length distributions and low rates of shoot length growth led to flat-topped crowns in the bog. Average needle age was independent of $Q_{\text {int }}$, but was larger in the infertile site. Thus, reduced rates of foliage production in the infertile site were somewhat compensated for by increased foliage longevity, and we suggest that shoot growth rates may have directly controlled the needle life span via reduced requirements for nutrients for the growth and via reduced selfshading within the canopy. Needle age and $Q_{\text {int }}$ independently affected needle structure. Needle age only moderately altered needle nutrient contents, but the primary age-related modification was the scaling of needle density with age. The density was similarly modified by age in both sites, but the needles were denser in the infertile site. Given that denser needles are more resistant to mechanical injury, larger density may provide an additional explanation for enhanced longevity in the infertile site. Our study demonstrates that site fertility is an important determinant of the plastic modifications in crown geometry, and needle life span in P. sylvestris.
\end{abstract}

bifurcation ratio / branching / irradiance / leaf life span / leaf density / site fertility

Résumé - Longévité des aiguilles, croissance des pousses et fréquence de ramification en relation avec la fertilité du site et les conditions de lumière dans la canopée de Pinus sylvestris. Les changements dans la morphologie des aiguilles, l'âge moyen des aiguilles, la croissance en longueur des pousses, la fréquence de la ramification ont été étudiés en réponse à la densité du flux quantique intégré $\left(Q_{\text {int }}\right)$ moyen saisonnier chez Pinus sylvestris L. dans un site fertile (anciennement cultivé) et dans un site pauvre (tourbière). Dans le site fertile, les arbres étaient âgés de 30 ans, avec une hauteur dominante de $17-21 \mathrm{~m}$, et une teneur en azote $\left(\mathrm{g} \mathrm{kg}^{-1}\right.$ de matière sèche) moyenne de $15,3 \pm 1,1$ dans les aiguilles de l'année. Dans le site pauvre, les arbres, âgés de 50 à 100 ans, avaient une taille de 1 à $2 \mathrm{~m}$, la teneur en azote des aiguilles était de $8,6 \pm 1,2 \mathrm{~g} \mathrm{~kg}^{-1}$. Les relations entre les variables ont été étudiées en utilisant les analyses de corrélation linéaire et de régression. Lorsque l'irradition est croissante, la longueur de la pousse $\left(L_{\mathrm{s}}\right)$ et le rapport de ramification $\left(R_{\mathrm{b}}\right.$, nombre de pousses de l'année par nombre de pousse formées au cours de l'année précédente) augmentent dans le site fertile, mais pas dans le site pauvre. Malgré une fréquence plus élevée de ramification, le contrôle apical est exacerbé par une irradiation plus élevée dans le site fertile. Les distributions des longueurs de pousse deviennent plus pointues (kurtosis positive) et biaisées vers les valeurs les plus faibles de $L_{\mathrm{S}}$ (skewness positive) avec un $Q_{\text {int }}$ en augmentation dans ce site. Les fortes valeurs de $R_{\mathrm{b}}$, combinées avec des distributions skewness des longueurs de pousses conduisent à des canopées coniques dans le site fertile. Par opposition, un rapport plus faible de la ramification, distributions normales des longueurs de pousses, et une faible croissance en longueur des pousses conduisent à la formation de canopées aplaties dans la tourbière. L'âge moyen des aiguilles était indépendant du $Q_{\text {int }}$, mais il était plus élevé dans le site le plus pauvre. Cependant, les taux réduits de production foliaire dans la station pauvre étaient, en quelque sorte, compensés par l'accroissement de longévité du feuillage, et nous suggérons que les taux de croissance des pousses peuvent avoir contrôlé directement la durée de vie des aiguilles par une réduction des besoins en nutriments pour la croissance et par une réduction de l'ombre dans la canopée. L'âge des aiguilles et $Q_{\text {int }}$ affectent indépendamment la structure des aiguilles. L'âge des aiguilles modifie seulement modérément la teneur en nutriments des aiguilles, mais la modification primaire liée à l'âge, était l'échelle de densité d'aiguilles. La densité était pareillement modifiée par l'âge dans les deux stations, mais les aiguilles étaient plus denses dans le site pauvre. Étant donné que des aiguilles plus denses sont plus résistantes aux blessures mécaniques, une plus grande densité peut fournir une explication additionnelle à la longévité renforcée dans les stations pauvres. Notre étude démontre que la fertilité de la station est un important déterminant des modifications plastiques de la géométrie de la couronne et la durée de vie des aiguilles chez $P$. sylvestris.

rapport de bifurcation / ramification / irradiance / durée de vie de la feuille / densité de feuille / fertilité de la station

* Correspondence and reprints

Fax: 003727366021; e-mail: ylo@zbi.ee 


\section{INTRODUCTION}

Crown architectural characteristics control the light harvesting efficiency of the canopy and species competitive potential [40, 64, 78, 84]. Differences in branching angle, branch length, and frequency of branching modify the aggregation of the foliage on the branches [19, 20, 40, 78], and thereby change the degree of self-shading within the canopy. Because the requirements for efficient light usage and acquisition vary with incident quantum flux density [64], a specific canopy constitution is not appropriate for all natural light levels. As the result of evolutionary adaptations in crown architecture to incident irradiance, there exists an array of various crown morphologies, and genetic heterogeneity in crown geometry provides a major explanation for species separation along gap-understory gradients [40, 84].

The species also possess considerable phenotypic plasticity for modification of canopy architecture, and thus, the foliar exposition characteristics [64]. Understory individuals of many plant species have flat crowns with the foliage arranged in a few planar layers to minimize self-shading within the canopy $[11,38,39,74,77]$. In contrast, plants in open habitats have conical crowns with a large number of leaf layers $[3,6$, $39,60,74,88$ ] that have a greater within canopy shading, but larger photosynthesizing leaf area. Such important alterations in crown shape are the consequence of light-related adaptability in branching frequency, branch length and branching angles $[11,15,41,65,76,77,81]$. Thus, understanding the environmental modifications in these characteristics is of paramount significance to characterize tree crown growth and light interception capacity $[21,36]$.

Apart from light, all environmental and soil variables that modify growth and development may potentially have important influences on canopy geometry, but much less is known of canopy morphological responses to these external factors [84]. There is evidence that, in conifers, branchiness may increase with decreasing site water availability [5]. In addition, increases in soil nutrient availability generally lead to enhanced branch extension growth [47, 67], as well as higher fractional biomass investment in foliage [59], and greater total plant foliar area [47, 70, 73]. The branching responses to nutrient availability have not been investigated extensively in trees, and it is not clear whether the nutrientrelated increase in branch extension is sufficient to support the extra foliar area, or whether the improved nutrition also leads to greater shoot production and more frequent branching. However, enhanced branching in higher nutrient availability is likely, because increases in branch length only, lead to larger biomass costs for mechanical support of branches [20, 46]. In herbaceous species, there is evidence of more frequent branching at higher nutrient availabilities [73], but the potential effects of nutrient limitations on plastic changes of crown architecture to light availability have not been characterized.

Adjustments in needle longevity also influence the total foliar area on the tree, and thereby the self-shading within the canopy. There is phenomenological evidence that decreases in light $[37,39,45,72]$ or nutrient availability [66] may result in increases in average needle life span, but the mechanisms responsible for extended needle longevity are still not entirely understood. Despite the lack of knowledge at the mechanistic level, such increases in needle longevity are relevant, and may largely compensate for the limited new foliage production in plants growing in shortage of light and/or nutrients. Moreover, limited shoot growth may directly lead to greater needle life span because of reduced self-shading within the canopy [1]. Thus, changes in crown architecture and in needle longevity may be closely interrelated.

We studied relationships of shoot growth, branching frequency and average needle age versus long-term integrated average quantum flux density in infertile and fertile sites in temperate conifer species Pinus sylvestris L. This species colonizes a wide range of early-successional habitats with strongly varying soil water and nutrient availabilities [42, 58], and is apparently a very plastic species that may readily change the crown architectural variables [36] and biomass allocation $[33,34]$ in response to changes in light availability. The primary objective of our study was to determine whether both the light and nutrient availabilities alter canopy architecture and needle life span, and whether the effects are interactive or independent. Although $P$. sylvestris is a plastic species, we have previously demonstrated that its ability for needle physiological and morphological [55] and shoot architectural [54] acclimation to light availability is considerably lower in the low than in the high fertility site. Thus, we expected similar differences in the plasticity also in canopy architecture. The conifers strongly reduce foliar area in response to decreases in soil nutrient availability [2, 42, 86], and it is logical to assume that the investments in woody support framework also parallel the major changes in needle area. As the characteristics of canopy architecture, we study average shoot lengths, shoot length distributions and branching frequency, which collectively allow quantitative estimation of conifer crown development [36].

To gain mechanistic insight into the variability in needle longevity between and within the sites, we also studied foliage structure, and needle nitrogen and phosphorus contents in needles of various age. Given that light and nutrient availabilities may independently modify needle morphological variables in $P$. sylvestris [55], and that these characteristics may directly alter leaf life span by altering the sensitivity of the foliage to mechanical damage [51], we hypothesized that light availability and site fertility have independent effects on needle longevity as well, and that these effects are related to site-to-site differences in needle morphological characteristics.

\section{MATERIALS AND METHODS}

\subsection{Study sites}

A monospecific even-aged homogeneous Pinus sylvestris plantation (1400 trees ha ${ }^{-1}$, 29-31 years old, dominant height 17$21 \mathrm{~m}$ ) on an old field at Ahunapalu, Estonia (58 $19^{\prime} \mathrm{N}, 27^{\circ} 17^{\prime} \mathrm{E}$, elevation ca. $60 \mathrm{~m}$ above sea level) was chosen as a representative nutrient-rich habitat. The soil was a pseudogley with moderately acidic ( $\mathrm{pH}$ in $1 \mathrm{M} \mathrm{KCl}$ of 4.3) humus horizon ([55] for specific details). In the understory, the dominants were the shrub Rubus idaeus L. and the herbaceous species Epilobium angustifolium L., Impatiens parviflora DC. and Urtica dioica L., which are indicators of nitrogen-rich early-successional habitats [16]. 

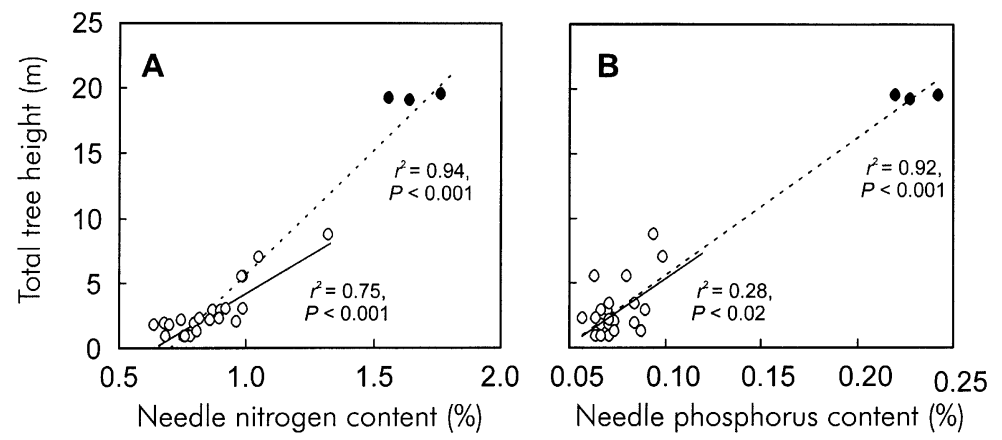

Figure 1. Correlation of the sampled tree height with the nitrogen $(\mathbf{A})$ and phosphorus $(\mathbf{B})$ contents of uppermost unshaded foliage (integrated quantum flux density $Q_{\text {int }}>30 \mathrm{~mol} \mathrm{~m}^{-2} \mathrm{~d}^{-1}$ ). The linear regressions were fitted to the entire set of data (dashed lines, filled symbols correspond to the fertile, and open symbols to the infertile site), and separately to the infertile habitat (solid lines).

The nutrient-limited site was a scattered woodland $\left(200\right.$ trees $\left.^{-1}\right)$ dominated by $P$. sylvestris and Betula pubescens Ehrh. at Männikjärve raised bog, Endla State Nature Reserve, Estonia $\left(58^{\circ} 52^{\prime} \mathrm{N}, 26^{\circ} 13^{\prime} \mathrm{E}\right)$ on thick - up to $8 \mathrm{~m}$ in the centre of the bog Sphagnum peat [85]. The average height of ca. 50-100 year-old trees was only 1-2 m. The organic soil was strongly acidic throughout the entire profile $\left(\mathrm{pH}_{\mathrm{KCl}}=2.59\right)$. Eriophorum vaginatum L., Rhynchospora alba (L.) Vahl and Scheuchzeria palustris L. dominated the herb layer, and Calluna vulgaris (L.) Hull, Chamaedaphne calyculata (L.) Moench, Empetrum nigrum L. and Ledum palustre L. the dwarf-shrub layer. A thorough description of this site is given in Niinemets et al. [55]. According to the previous study, the plants were limited both by low $\mathrm{P}$ and $\mathrm{N}$ availabilities in this site [55].

\subsection{Foliage sampling and long-term light availability estimations}

Because the fertile site was very homogeneous, three 19-20 m tall trees in the centre of the forest were selected for detailed sampling. In the infertile site, 22 trees with heights ranging from 0.8 to $2 \mathrm{~m}$ were selected in the central areas of the bog. In addition, seven larger trees (height 2.9-8.7 m) with apparently better nutrition were chosen at the edge of the bog and on the adjacent dried peatlands to attain a larger gradient in nutrient availability [29]. The trees sampled in this site were 20-150 years old according to the increment cores taken at the ground level (average $\pm \mathrm{SE}=43 \pm 8 \mathrm{yr}$.). Only mature, reproductive phase trees were considered, and we did not observe any significant effect of tree age on studied crown and foliage characteristics $(P>$ $0.05)$. Insignificant effects of tree age on foliage structure and branching are in agreement with previous observations in mature trees $[49,52]$. In fact, tree-to-tree differences in height were primarily associated with differences in tree nutrient status (figure 1). Both the $\mathrm{N}$ (figure 1A) and $\mathrm{P}$ (figure 1B) contents of the uppermost unshaded needles were positively correlated with tree height for both sites pooled, and also for the infertile site considered separately. This suggests that although there were site differences in average tree age, comparisons of foliage and crown characteristics between the sites are valid.

The sampling was conducted in Sept. 1998 in both sites, and in Oct. 1999 in the fertile site, and late Aug. 1999 in the infertile site. Entire branches $(n=68)$ were harvested along the light gradient in tree canopies. In the fertile site, 4-5 branches were taken from each tree. In the infertile stand, 2-4 branches per tree were sampled. After collection, the branches were enclosed in plastic bags, and transported to the laboratory within an hour from collection. Although needle morphological characteristics and nutrient contents may potentially vary during the season $[30,43]$, such effects were not evident in our data [55].

Hemispherical photographs were taken above each sample branch for estimation of long-term light availability in branch growth location. The seasonal (May 1-July 31) average daily integrated photosynthetic quantum flux densities $\left(Q_{\mathrm{int}}, \mathrm{mol} \mathrm{m} \mathrm{m}^{-2} \mathrm{~d}^{-1}\right)$ in the canopy were calculated by a method combining the hemispherical photographs and measurements of solar radiation components. From the hemispherical photographs, the fraction of penetrating diffuse solar radiation for uniformly overcast sky conditions $\left(I_{\mathrm{dif}}\right)$, and the fraction of potential penetrating direct radiation between summer solstice and 30 days from summer solstice $\left(I_{\text {dir }}\right)$ were computed as detailed in Niinemets et al. [55]. From these values, the relative amount of global solar radiation incident to the sample branches, $\left(I_{\text {sum }}\right)$ was found as:

$$
I_{\text {sum }}=p_{\text {dif }} I_{\mathrm{dif}}+\left(1-p_{\mathrm{dif}}\right) I_{\mathrm{dir}},
$$

where $p_{\text {dif }}$ is the ratio of diffuse to global solar radiation above the canopy. An estimate of $p_{\text {dif }}$ (average $\pm \mathrm{SE}=0.447 \pm 0.023$ ) was derived from measurements in Tõravere Actinometric Station (58 $\left.16^{\prime} \mathrm{N}, 26^{\circ} 28^{\prime} \mathrm{E}\right)$.

The global solar radiation data $\left(\mathrm{MJ} \mathrm{m}^{-2} \mathrm{~d}^{-1}\right)$ of Tõravere Actinometric Station, and a conversion factor of $1.92 \mathrm{~mol} / \mathrm{MJ}$ [53] were used to transform the values of $I_{\text {sum }}$ to $Q_{\text {int }}$ according to Niinemets et al. [53]. Using this conversion factor, an average value of $Q_{\text {int }}$ above the canopy, $Q_{\mathrm{int}}^{0}=40.4 \mathrm{~mol} \mathrm{~m}^{-2} \mathrm{~d}^{-1}$, was estimated for a period May 1, 1999 to July 31, 1999, which was a period of active leaf growth and development in both sites. $Q_{\text {int }}$ for each sample location in the canopy was determined as the product of $Q_{\text {int }}^{0}$ and $I_{\text {sum. }}$.

\subsection{Needle, shoot and branch morphological measurements}

In the laboratory, harvested branches were immediately separated between various shoot age classes. The shoots in each age classe were counted, their length $\left(L_{\mathrm{S}}\right)$ was measured, and the fresh mass of shoots in each age class (needles and shoot axes pooled) was determined. Pinus sylvestris forms only one shoot flush per year, and bud scale scars at the beginning of each annual growth were used for shoot census. Overall, more than 6200 shoots from 68 branches were analysed.

We calculated skewness $(\zeta)$ and kurtosis ( $\kappa)$ for the distribution of shoot lengths in a given branch. Values of $\zeta$ and $\kappa$ were computed separately for each shoot age class on the branch, provided that at least 20 shoots were present for the specific age-class. Distribution skewness describes the degree of asymmetry of a distribution around 
its mean, whereas distributions with a negative skewness are biased towards larger values, those with a positive skewness are biased towards smaller values compared with the mean of the dataset. Distribution kurtosis characterises the relative peakedness or flatness of the distribution relative to the normal distribution $(\kappa=0)$. Negative values of kurtosis indicate flatter, and positive values peaked distributions relative to the normal distribution.

Three representative shoots from each shoot age class were selected for detailed foliar morphological measurements. From each shoot, five to ten needles were randomly taken and measured for needle length $\left(L_{\mathrm{n}}\right)$, thickness $(T)$, and width $\left(W_{\mathrm{n}}\right)$ by precision callipers. The total needle area, $A_{\mathrm{T}}$ was computed as the product of needle circumference $(C)$ and $L_{\mathrm{n}}$ approximating the needle crosssection geometry by half-ellipse [55]. The projected needle area, $A_{\mathrm{P}}$, was computed as $W_{\mathrm{n}} L_{\mathrm{n}}$. The sample needles were weighted after oven-drying at $70{ }^{\circ} \mathrm{C}$ for at least $48 \mathrm{~h}$, and needle dry mass per unit total $\left(M_{\mathrm{A}}, \mathrm{g} \mathrm{m}^{-2}\right)$ and projected area $\left(M_{\mathrm{P}}\right)$ were calculated. The assumption of half-elliptical needle cross-section geometry was also employed to find needle volume $(V,[55])$ and the $V / A_{\mathrm{T}}$ ratio $(\mathrm{mm})$. Given that needle dry mass per unit area, $M_{\mathrm{A}}$, is a product of $V / A_{\mathrm{T}}$ and needle density [50], needle density $\left(D, \mathrm{~g} \mathrm{~cm}^{-3}\right)$ was computed as $M_{\mathrm{A}} /\left(V / A_{\mathrm{T}}\right)$. All shoots in each age-class were dried at $70^{\circ} \mathrm{C}$, separated between needle and woody biomass, and weighted. Shoot dry matter content $\left(\delta_{\mathrm{s}}\right)$ was further calculated as the weighted average of needle and shoot axis dry to fresh mass ratios. For 26 shoots, needle and stem fresh masses were determined separately, allowing to compute needle $\left(\delta_{\mathrm{n}}\right)$ and shoot axis $\left(\delta_{\mathrm{a}}\right)$ dry matter contents. The statistical comparison of these sample shoots demonstrated that $\delta_{\mathrm{a}}$ was significantly larger than $\delta_{\mathrm{n}}(P<0.05$ according to a $t$-test $)$, but also that the differences were minor (average $\pm \mathrm{SE}=$ $0.612 \pm 0.020 \mathrm{~g} \mathrm{~g}^{-1}$ for $\delta_{\mathrm{a}}$ and $0.600 \pm 0.032 \mathrm{~g} \mathrm{~g}^{-1}$ for $\delta_{\mathrm{n}}$ ).

\subsection{Calculation of shoot bifurcation ratio}

Assuming that branching in plants follows a geometric sequence, the frequency of branching is often described by the bifurcation ratio $[8,41,81,83], R_{\mathrm{b}}$ :

$$
R_{\mathrm{b}}=\frac{N_{\mathrm{a}}}{N_{\mathrm{a}+1}},
$$

where $N_{\mathrm{a}}$ is the number of branches of age $a$ and $N_{\mathrm{a}+1}$ is the number of branches in the next older age-class $[61,87]$. In a more general form:

$$
N_{\mathrm{a}}=N_{\mathrm{n}} R_{\mathrm{b}}^{1-\mathrm{a}},
$$

where $N_{\mathrm{n}}$ is the number of shoots in the youngest age class $(a=1)$. Logarithming equation (3) allows to linearize the relationship, and thus, we calculated the average bifurcation ratio from the slope of $\log N_{\mathrm{a}}$ vs. $a$ :

$$
\log N_{\mathrm{a}}=\log \left(N_{\mathrm{n}} R_{\mathrm{b}}\right)-a \log R_{\mathrm{b}} .
$$

Only branches with a minimum of four shoot age classes present were used for the analysis, and the maximum number of shoot age classes available was 15. Equation (3) gave good fits to the data (figure 2) with the fractions of explained variance $\left(r^{2}\right)$ generally exceeding 0.90 . This indicates that the concept of bifurcation ratio is valid for Pinus sylvestris, and also that the value of $R_{\mathrm{b}}$ was almost constant throughout the life span of the branches. Thus, $R_{\mathrm{b}}$ may be used as an estimate of long-term trends in crown architectural development in this species.

\subsection{Determination of average needle age}

Dry mass-averaged needle age $(\Lambda)$ was computed for each branch as:

$$
\Lambda=\frac{\sum_{\mathrm{i}=1}^{\mathrm{i}=n} \Lambda_{\mathrm{i}} M_{\mathrm{i}}}{M_{\mathrm{T}}},
$$

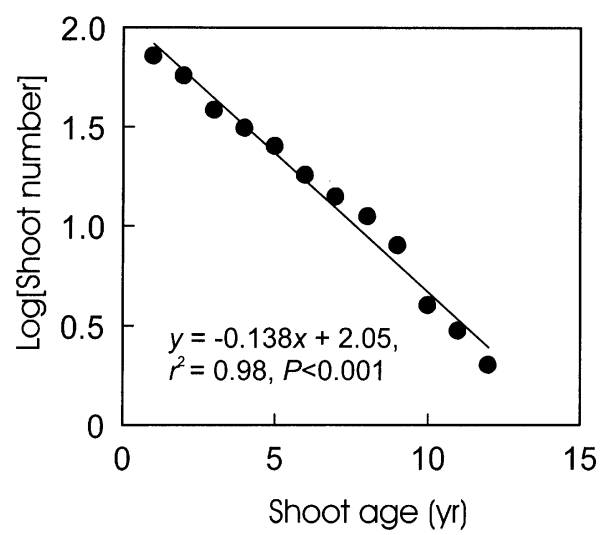

Figure 2. Logarithmed number of shoots vs. shoot age relationship for a Pinus sylvestris branch collected in the infertile site. The bifurcation ratio, $R_{\mathrm{b}}=1.34$, was calculated from the slope of the linear regression according to equation (4). Current-year needles were assigned an age of $1.0 \mathrm{yr}$.

where $i$ is the number of specific needle age class of age $\Lambda_{\mathrm{i}}, M_{\mathrm{i}}$ is the dry mass of all needles in this age-class, $n$ is the number of needle age-classes present and $M_{\mathrm{T}}$ is the total needle dry mass on the branch. Current-year needles were assigned an age of $1.0 \mathrm{yr}$. in these calculations. It is important that the average needle age for a specific branch depends not only on needle longevity, but also on shoot bifurcation ratio. For a common needle life-span, more frequent branching leads to a greater fraction of needles present in younger needle age classes than in the case of less frequent branching.

\subsection{Measurement of needle carbon, nitrogen and phosphorus contents}

Total needle nitrogen and carbon contents were estimated by an elemental analyser (CHN-O-Rapid, Foss Heraeus GmbH, Hanau, Germany), and phosphorus contents by inductively coupled plasma emission spectroscopy (Integra XMP, GBC Scientific Instruments, Melbourne, Australia). In some cases, standard Kjeldahl digestion was applied, and $\mathrm{N}$ content was estimated by indophenol method and $\mathrm{P}$ content by molybdenum blue method [28]. All methods gave essentially identical estimates of the contents of chemical elements [55].

\subsection{Statistical analysis of data}

To analyse the relationships among foliage nutrient content, shoot irradiance, needle age, shoot branching and needle architecture, linear correlation and regression techniques were employed [71]. All statistical effects were considered significant at $P<0.05$. Given that the characteristics of shoot length distribution, shoot length as well as the bifurcation ratios of the uppermost shoots in the tree crown differed considerably from the rest of the data, we also examined the leverage statistics $(h)$ and studentized residuals to determine whether these cases influenced the regression models more than others [4]. The values of leverage statistic, which vary from 0.0 (no effect on the model) to 1.0 (completely determining the model), were always less than 0.25 , suggesting that these data did not bias the regressions considerably. This conclusion was further corroborated by the finding that removal of the uppermost data points did not change the conclusions with respect to the statistical significance of the relations (figures 3-5). 

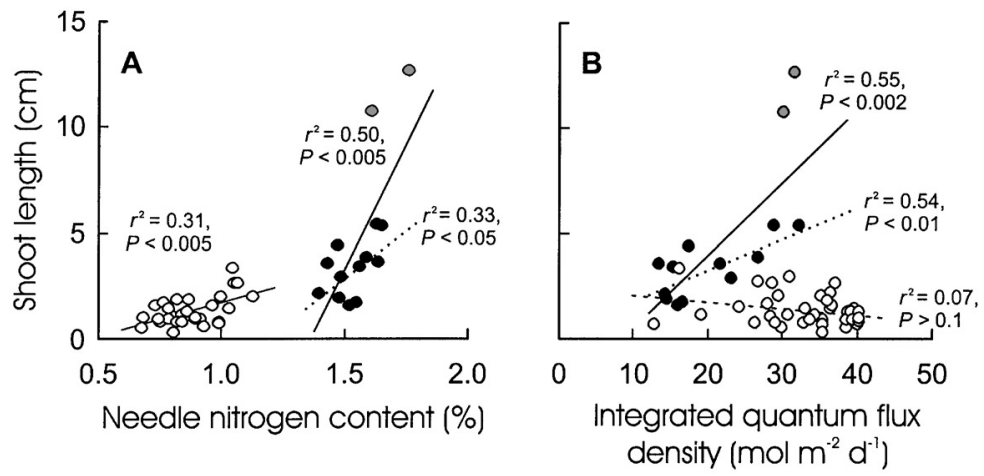

Figure 3. Dependence of average length of current year shoots on (A) needle nitrogen content and (B) on integrated photosynthetic quantum flux density $\left(Q_{\text {int }}\right)$ in the infertile (open symbols) and fertile (black and shaded symbols) site. Lengths of all shoots on a given branch were measured. $Q_{\text {int }}$ is a daily average value for May 1-July 31, 1999, during which growth and development of current year needles occurred. Data were fitted by linear regressions. In the fertile site, the uppermost two data points (shaded symbols) had large leverage, and the regressions were also computed without these data, dotted lines). Statistically non-significant regression in B is shown by a dashed line.

If $Q_{\text {int }}$ was a significant determinant of a specific dependent variable, $Y_{\mathrm{i}}$, site differences (Site, fixed effect) were separated by analyses of covariance:

$$
Y_{\mathrm{i}}=\mu+Q_{\text {int }}+\text { Site }+Q_{\text {int }} \text { X Site }+\varepsilon,
$$

where $\mu$ is the overall mean of the dependent variable and $\varepsilon$ is the error variance. If the interaction term, $Q_{\text {int }} \mathrm{X}$ Site, was not significant $(P>0.05)$ the separate slope model (Eq. (6)) was followed by the common slope ANCOVA model to test for the intercept differences. One-way analysis of variance was employed if $Q_{\text {int }}$ was not a significant determinant of the dependent variable. The comparisons were conducted with and without the potentially influential upper canopy values of the fertile site. However, the observed differences were not sensitive to these data, indicating that the relationships were robust.

Tree crowns are composed of modular units [68], and there is a growing consensus that these moduli - branches - function essentially autonomously $[32,69,74,75]$. Therefore, branch rather than tree was the experimental unit in the current study. However, branches on the same tree share a common pathway for nutrient, water and assimilate transport, and the repeated measurements conducted within a tree may confound the true statistical effect of irradiance and needle nutrient contents on shoot growth and branching morphology. We tested the possible tree effect $(T)$ within each site by the following model:

$$
Y_{\mathrm{i}}=\mu+X_{\mathrm{i}}+T+\varepsilon,
$$

where $X_{\mathrm{i}}$ is the independent variable ( $Q_{\text {int }}$ or leaf $\mathrm{N}$ or $\mathrm{P}$ content). The statistical significance of the effect of the independent variable on $Y_{1}$ was always the same whether or whether not $T$ was included. Thus, these analyses demonstrated that the reported statistical effects were not attributable to the repeated measurements within the trees, further supporting the autonomy of branches within the tree.

As a second way to test for the possible effect of repeated measurements, we also computed the average values of all variables for each tree. Again, the statistical significance of all relationships was qualitatively the same for this and for the entire dataset as reported in the Results.

Overall, all the information was available for 14 branches from the fertile site and for 54 branches from the infertile site. The bias towards the infertile site reflects the circumstance that previous investigations have primarily studied $P$. sylvestris characteristics in relation to light environment in nutrient rich sites (e.g., [33, 35, 36]). Due to the constraints applied for shoot length distributions and for bifurcation ratio calculations, the number of data points was reduced for these characteristics.

\section{RESULTS}

\subsection{Shoot length and shoot length distributions in relation to light and site fertility}

Average length of current-year shoots $\left(L_{\mathrm{S}}\right)$ increased with increasing needle nitrogen content per mass in both sites (figure $3 A, r^{2}=0.33, P<0.02$ for the correlation with the average values per tree in the infertile site). However, $L_{\mathrm{S}}$ was positively correlated with needle phosphorus content per mass $\left(r^{2}=0.40, P<0.02\right)$ and integrated quantum flux density ( $Q_{\text {int }}$, figure $3 B$ ) only in the fertile site, but not in the infertile site. Because the average lengths of different age-classes were strongly $\left(r^{2}>0.80\right)$ correlated, the relationships were similar with shoot lengths of other shoot age classes.

Shoot lengths were similar in low irradiance at the fertile and infertile sites (figure $3 B$ ), but the values of $L_{\mathrm{S}}$ were lower in high light at the infertile habitat, indicating a lower plasticity with respect to growth adjustment to light in this site. According to one-way ANCOVA (site as the categorical variable, $Q_{\text {int }}$ as the covariate), both the site, and site $\mathrm{X} Q_{\text {int }}$ interaction were significant determinants of $L_{\mathrm{s}}(P<0.001)$.

Nitrogen and phosphorus contents per unit dry mass were independent of $Q_{\text {int }}$ at the infertile site $\left(r^{2}=0.05, P>0.2\right.$ for $\mathrm{N}$, and $r^{2}=0.00, P>0.8$ for $\mathrm{P}$ ), but strong positive dependencies were observed at the fertile site $\left(r^{2}=0.66\right.$, $P<0.001$ for $\mathrm{N}$ and $r^{2}=0.36, P<0.05$ for $\mathrm{P}$, see also [55]) complicating the correlations between light, nutrients and shoot characteristics. Nevertheless, when the interrelations between N, P and light availability were accounted for by a multiple linear regression analysis, only $Q_{\text {int }}$ was a significant determinant of most of foliar characteristics at the fertile site.

Kurtosis and skewness of the $L_{\mathrm{S}}$ distributions were positively correlated $\left(r^{2}=0.71, P<0.001\right.$ for the fertile, and $r^{2}=0.44, P<0.001$ for the infertile site). Kurtosis increased with increasing irradiance (figure $4 A$ ) at the fertile site, indicating 

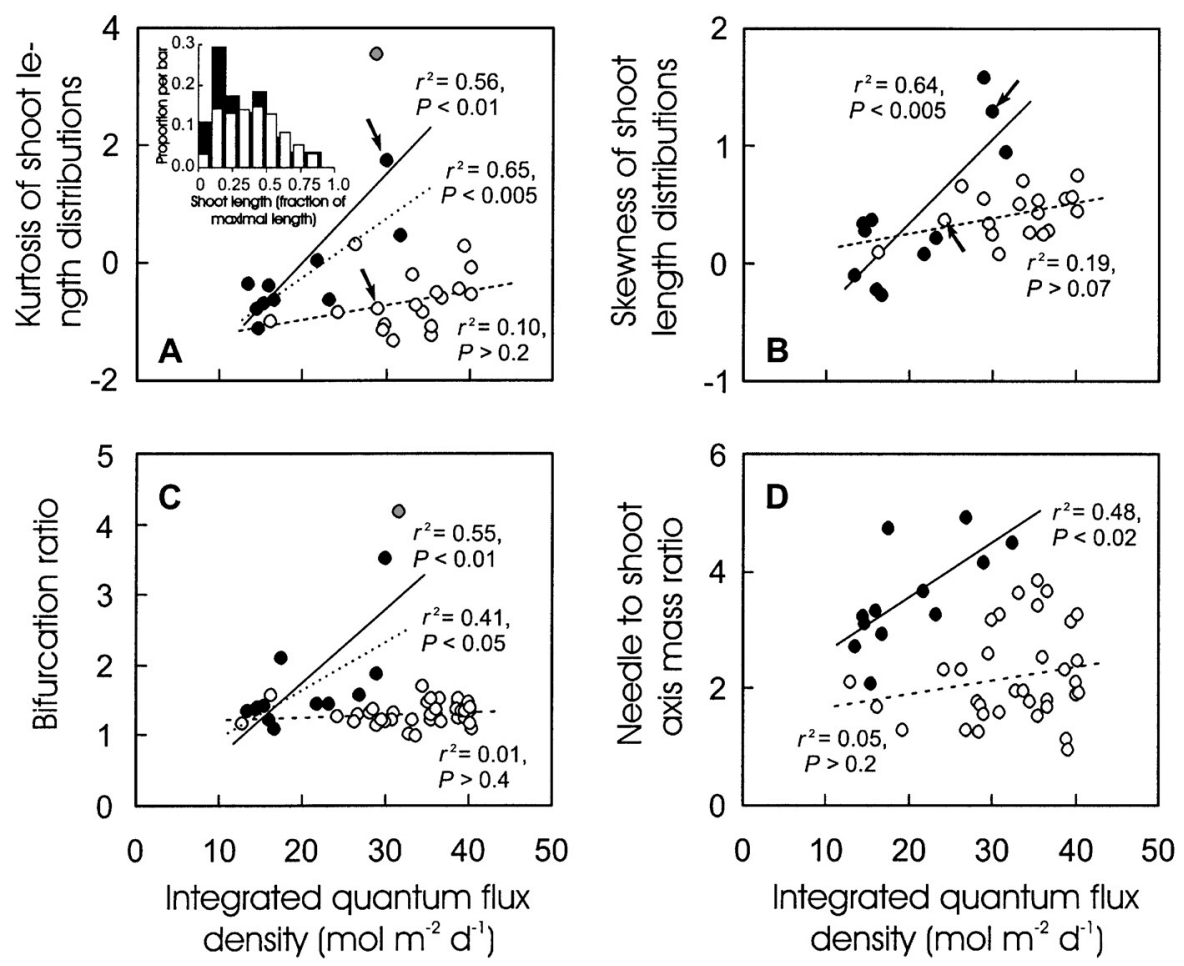

Figure 4. Effects of $Q_{\text {int }}$ on the distribution characteristics of the length of current year shoots $(\mathbf{A}, \mathbf{B})$, on the bifurcation ratio $(\mathbf{C}$, Eqs. (2-4), figure 2), and the partitioning of dry mass between needles and shoot axes (D). The inset in A shows frequency distributions of normalised shoot length for representative branches (denoted by arrows in A and B) from the fertile (filled bars) and infertile sites (open bars). Data presentation as in figure 3.

that shoot distributions became more peaked at higher irradiance. Similarly, the skewness scaled positively with irradiance in the fertile site (figure $4 B$ ), suggesting that there were less long shoots at high irradiance than expected on the basis of normal distribution. Thus, the apical dominance increased with increasing irradiance in this site. Skewness and kurtosis were independent of irradiance (figure $4 A, B$ ) and $\mathrm{N}$ content at the infertile site (for the average values per tree, $r^{2}=0.11$, $P>0.3$ for the skewness, and $r^{2}=0.17, P>0.2$ for the kurtosis). Analyses of covariance demonstrated that the slopes of the kurtosis vs. $Q_{\text {int }}$ and skewness, vs. $Q_{\text {int }}$ relationships were significantly lower at the infertile site $(P<0.01)$. Thus, the shoot length distributions were essentially normal at the infertile site, and became increasingly asymmetric and peaked with increasing irradiance at the fertile site.

\subsection{Effects of irradiance and nutrient availability on branching frequency and biomass partitioning within the shoot}

The finding that the lengths of shoots of all age classes were strongly correlated, indicates that the growth conditions were similar throughout the branch life time, and supports the calculation of the bifurcation ratio as the slope of the shoot number vs. shoot age relationship (figure 2, Eq. (4)).

The bifurcation ratio (figure 2, Eq. (4)) at low to moderate light $\left(Q_{\text {int }}<20 \mathrm{~mol} \mathrm{~m}^{-2} \mathrm{~d}^{-1}\right)$ was not different between the infertile (average $\pm \mathrm{SE}=1.35 \pm 0.21)$ and fertile $(1.42 \pm 0.12)$ site (figure $4 C$, means were not significantly different at $P>0.7$ according to ANOVA). The bifurcation ratio scaled positively with irradiance in the fertile site (figure $4 C$ ), indicating that increased irradiance led to more frequent branching. In contrast, the bifurcation ratio did not respond to increases in irradiance in the infertile site, and the general mean of $1.314 \pm 0.025$ for all data from this site was similar to the value observed in low light in the fertile side.

The bifurcation ratio was positively related to average shoot length in both sites, but the explained variance was larger in the fertile than in the infertile site (figure $5, r^{2}=0.38$, $P<0.005$ for the correlation with the average values per tree in the infertile site). The slope of the $R_{\mathrm{b}}$ vs. $L_{\mathrm{S}}$ relationship of $0.26 \mathrm{~cm}^{-1}$ was larger $(P<0.001$ according to ANCOVA) in the fertile than in the infertile site $\left(0.07 \mathrm{~cm}^{-1}\right)$, demonstrating that the length of mother shoots controlled the branching less in the infertile site.

The ratio of current needle to shoot axis dry mass $(\gamma)$ was positively related to irradiance in the fertile site (figure $4 D$ ), but not in the infertile site. However, $\gamma$ was significantly lower $(P<0.001$, analysis of covariance) at the infertile than at the fertile site, indicating that biomass requirement for needle support was larger in the nutrient-poor site.

Shoot dry matter content $\left(\delta_{s}\right.$, weighted average of needle and shoot axis dry matter contents) was significantly larger $(P<0.001)$ with average $\pm \mathrm{SE}=0.551 \pm 0.010 \mathrm{~g} \mathrm{~g}^{-1}$ in the 


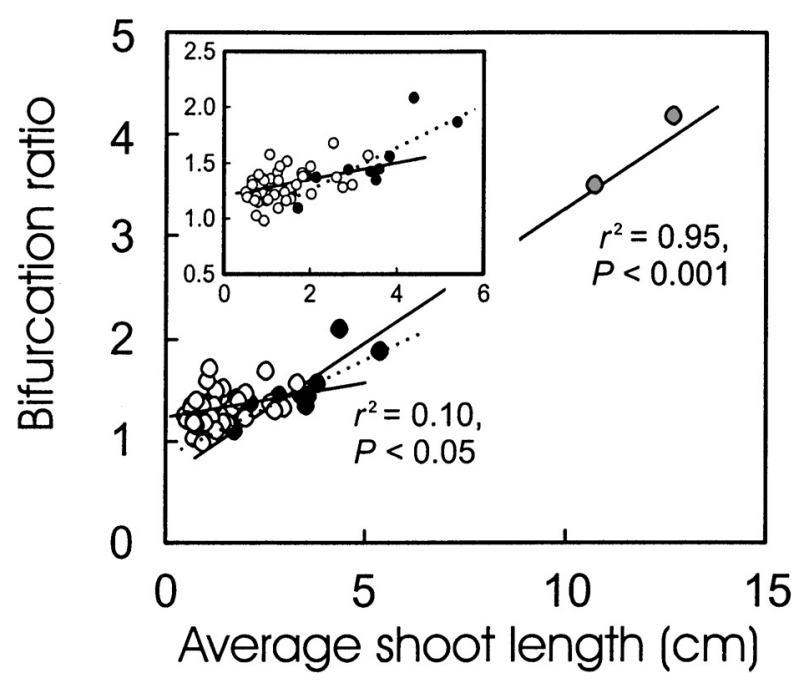

Figure 5. Correlations between average shoot length $\left(L_{\mathrm{S}}\right)$ and shoot bifurcation ratio, $R_{\mathrm{b}}$, in the fertile site (filled symbols) and in the infertile site (open symbols). Data presentation as in figure 3. The inset displays the relationship between $R_{\mathrm{b}}$ and $L_{\mathrm{s}}$ without the two uppermost data points in a better resolution $\left(r^{2}=0.68, P<0.005\right.$ for the fertile site).

infertile than in the fertile stand $\left(0.476 \pm 0.005 \mathrm{~g} \mathrm{~g}^{-1}\right)$. The ratio of needle to shoot axis dry mass was positively related to $\delta_{\mathrm{s}}$ in the infertile site $\left(r^{2}=0.18, P<0.001\right)$, but not in the fertile site $\left(r^{2}=0.00, P>0.9\right)$.

\subsection{Dependence of needle average age on light and nutrient availability}

The maximum needle age observed was six years at the infertile and four years at the fertile site, suggesting that the site fertility significantly altered needle longevity. When the sites were considered separately, mass-weighted average needle age $(\Lambda$, Eq. (5)) was independent of needle nitrogen content in both the infertile $\left(r^{2}=0.04, P>0.3\right)$ and fertile stand $\left(r^{2}=0.09, P>0.3\right)$. However, the needles were considerably older in the infertile site with an average $\Lambda \pm \mathrm{SE}$ for all shoots of $2.27 \pm 0.05 \mathrm{yr}$. than the needles in the fertile site $(1.70 \pm 0.05 \mathrm{yr}$., the means are significantly different at $P<0.001$ according to one way ANOVA). When the data for both sites were pooled, there was a strong negative correlation between needle nitrogen content and average needle age (figure 6A). A similar relationship was also observed for foliar $P$ contents $\left(r^{2}=0.48, P<0.001\right)$. The average needle age $(\Lambda)$ was not significantly influenced by irradiance (figure $6 B$ ).

In both sites, $\Lambda$ was negatively related to average shoot length $\left(r^{2}=0.16, P<0.02\right.$ for the infertile and $r^{2}=0.49$, $P<0.001$ for the fertile site). For all data pooled, the explained variance $\left(r^{2}\right)$ was $0.37(P<0.001)$, indicating strong interrelatedness of growth and needle longevity. $\Lambda$ was positively related to needle density $\left(r^{2}=0.18, P<0.01\right)$ and to shoot dry matter content $\left(r^{2}=0.14, P<0.005\right)$. Thus, apart from scaling with growth, life span of more resistant needles tends to be larger.

\subsection{Age effects on foliage morphological and chemical characteristics}

Needle to axis mass ratio decreased with increasing shoot age (figure 7 ), and this decrease was stronger in the fertile site $(P<0.001$ for the interaction term - age $\mathrm{X}$ site - according to a covariance analysis). Like for the current year shoots, the average ratio of needle to woody biomass of all needled shoot age classes pooled was significantly $(P<0.05$ according to one-way ANOVA) lower in the infertile $\left(1.84 \pm 0.10 \mathrm{~g} \mathrm{~g}^{-1}\right)$ than in the fertile site $\left(2.29 \pm 0.22 \mathrm{~g} \mathrm{~g}^{-1}\right)$.

Needle dimensions - length, width, and thickness - as well as needle total area $\left(A_{\mathrm{T}}\right)$, and $A_{\mathrm{T}}$ to projected needle area ratio were mainly affected by $Q_{\text {int }}$ in needles of all age classes, but were independent of needle age in both sites (table I). Needle dry mass per unit area $\left(M_{\mathrm{A}}\right)$ also increased with increasing irradiance (figure $8 A, B$ ), and was strongly affected by needle age (figure $8 A, C$, table $I$ ).

Given that $M_{\mathrm{A}}$ is the product of needle density $(D)$ and volume to $A_{\mathrm{T}}$ ratio $\left(V / A_{\mathrm{T}}\right)$, the effects of $Q_{\text {int }}$ and needle age on $D$ and $V / A_{\mathrm{T}}$ were also studied to unravel the age effects on $M_{\mathrm{A}}$. Needle age did not significantly influence $V / A_{\mathrm{T}}$, but
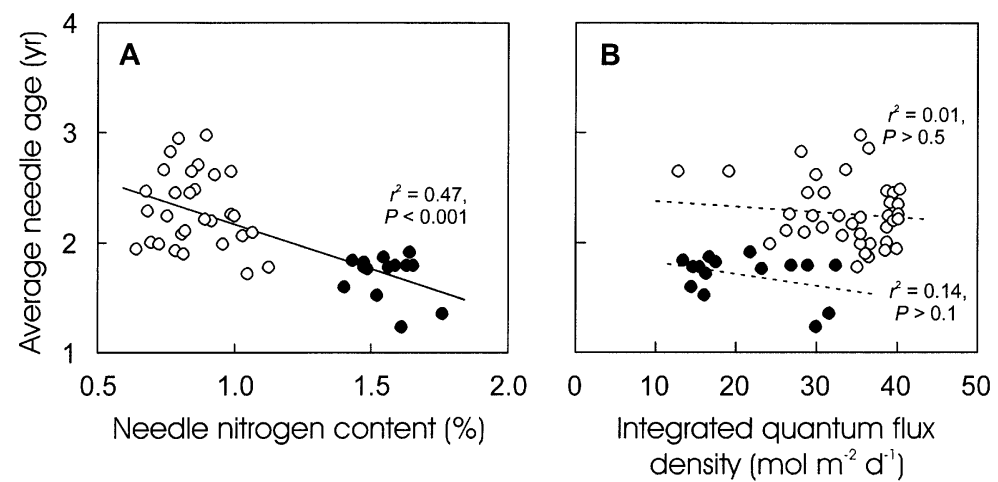

Figure 6. Average needle age ( $\Lambda$, Eq. (5)) as a function of needle nitrogen content $\left(N_{\mathrm{M}}, \mathbf{A}\right)$ and irradiance $(\mathbf{B})$. Within each site, $\Lambda$ and $N_{\mathrm{M}}$ were not significantly related $\left(r^{2}=0.11, P>0.2\right.$ for the infertile and $r^{2}=0.24, P>0.1$ for the fertile site). Given that neither the site effect at the common $N_{\mathrm{M}}$ nor the site $\mathrm{X} N_{\mathrm{M}}$ interaction were significant according to ANCOVA $(P>0.2)$, data were fitted by a single regression line in A. Symbols and regression lines as in figure 3. 


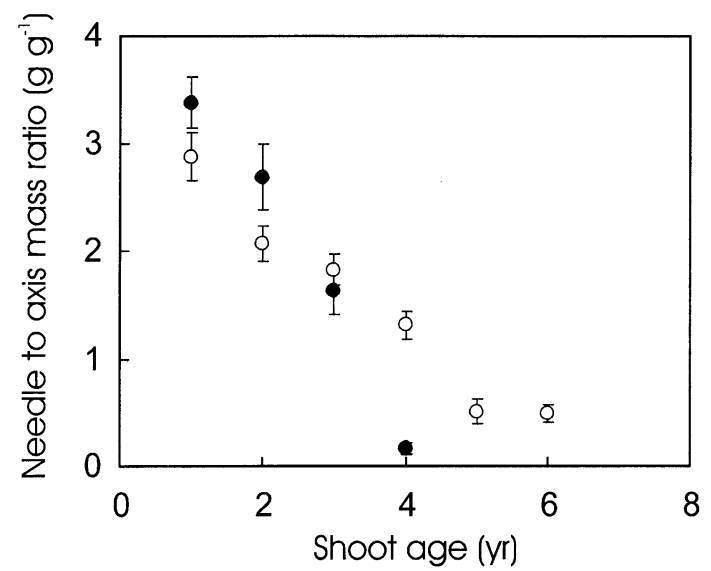

Figure 7. Needle to shoot axis dry mass ratio in relation to shoot age in the fertile (filled symbols) and infertile site (open symbols). According to a co-variation analysis (age as the covariate, site as the factor), both the site, and shoot age $\mathrm{X}$ site interaction were significant determinants of the mass ratio $(P<0.001$ for both).

needle density strongly increased with increasing age (table I), providing an explanation for the age-related increases in $M_{\mathrm{A}}$. At the fertile site, irradiance was positively correlated with both $D$ and $V / A_{\mathrm{T}}$, but more strongly with $V / A_{\mathrm{T}}$ (figure $8 B$ ) than with $D\left(r^{2}=0.16, P>0.06\right.$ for $1-\mathrm{yr}, r^{2}=0.35, P<0.05$ for $2-\mathrm{yr}$ and $r^{2}=0.03, P>0.8$ for 3 -yr needles). At the infertile site, similar fractions of explained variance were observed for both V/A $A_{\mathrm{T}}$ (figure $\left.8 D\right)$ and $D\left(r^{2}=0.13, P<0.02\right.$ for $1-\mathrm{yr}, r^{2}=0.14$, $P<0.02$ for 2 -yr and $r^{2}=0.10, P>0.06$ for 3 -yr needles).

Needle nitrogen contents, $N_{\mathrm{M}}$, were independent of needle age in the fertile site (table IA), but $N_{\mathrm{M}}$ increased in the second-year needles relative to the first-year needles in the infertile site (table $I B$ ), suggesting that older needles remained physiologically competent. Foliage carbon contents increased with increasing needle age in both sites (table I), possibly because of age-related accumulation of certain carbon-rich compounds such as lignin or terpenoids. Increases in foliar carbon content were paralleled by modifications in needle density (figure 9).

The explained variance of all leaf structure and chemistry vs. irradiance relationships generally decreased with increasing needle age, possibly indicating that needles became less plastic with advancing age. Despite this, the interaction term, age $\mathrm{X} Q_{\text {int }}$, was insignificant in all relationships $(P>0.2)$. Accordingly, age and light independently altered needle morphology and chemistry.

\section{DISCUSSION}

\subsection{Shoot growth characteristics}

Monotonic increases in height growth and length of individual shoots in response to irradiance are frequently
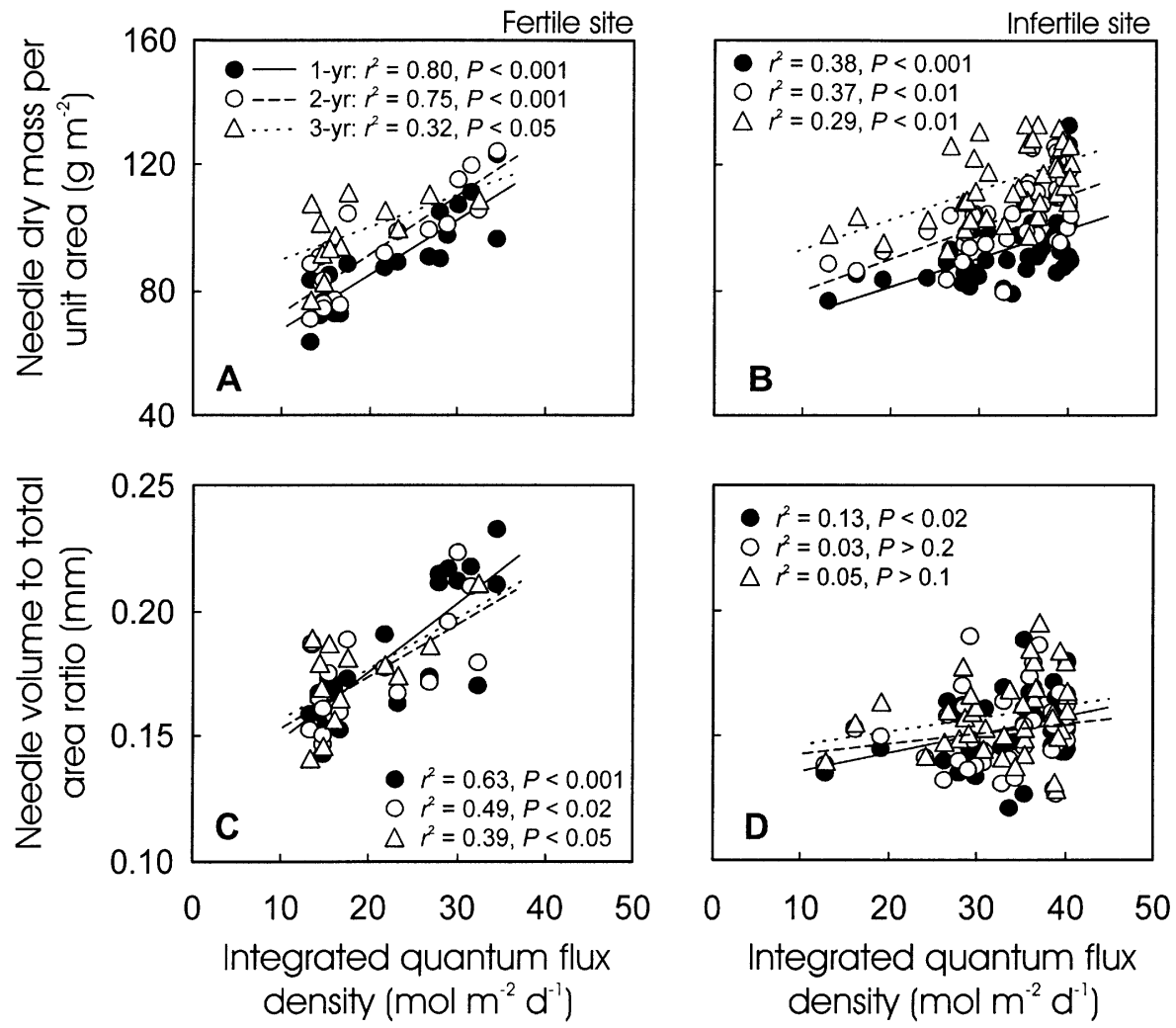

Figure 8. Correlations of $(\mathbf{A}, \mathbf{B})$ needle dry mass per unit area $\left(M_{\mathrm{A}}\right)$ and $(\mathbf{C}, \mathbf{D})$ needle volume to total area ratio $\left(V / A_{\mathrm{T}}\right)$ with $Q_{\text {int }}$ in needles of various age in the fertile $(\mathbf{A}, \mathbf{C})$ and the infertile site $(\mathbf{B}, \mathbf{D}) . M_{\mathrm{A}}$ is the product of $V / A_{\mathrm{T}}$ and needle density. Current-year needles were attributed an age of 1-yr. Data for each needle age-class were fitted by separate linear regressions as depicted in A. 
Table I. Needle morphological characteristics, and nitrogen and carbon contents (average \pm SE) in relation to needle age in the fertile (A) and the infertile (B) site, and the statistical significance of the effects of age and integrated quantum flux density $\left(Q_{\text {int }}\right)$ on needle variables ${ }^{1}$.

A. Fertile site

\begin{tabular}{|c|c|c|c|c|c|}
\hline \multirow[b]{2}{*}{ Variable } & \multicolumn{3}{|c|}{ Needle age } & \multicolumn{2}{|c|}{$P$} \\
\hline & $1-\mathrm{yr}$ & $2-y r$ & $3-\mathrm{yr}$ & Age & $Q_{\text {int }}$ \\
\hline Total needle area $\left(A_{\mathrm{T}}, \mathrm{mm}^{2}\right)$ & $164.6 \pm 8.9 a$ & $162 \pm 10 a$ & $160 \pm 10 a$ & ns. $^{2}$ & 0.001 \\
\hline$A_{\mathrm{T}}$ to projected area ratio $\left(A_{\mathrm{T}} / A_{\mathrm{P}}\right)$ & $2.588 \pm 0.016 a$ & $2.532 \pm 0.020 a$ & $2.562 \pm 0.022 a$ & ns. & 0.005 \\
\hline Dry mass per $A_{\mathrm{T}}\left(\mathrm{g} \mathrm{m}^{-2}\right)$ & $89.8 \pm 3.2 a$ & $95.1 \pm 3.7 b$ & $99.1 \pm 3.0 c$ & 0.001 & 0.001 \\
\hline Density $\left(\mathrm{g} \mathrm{cm}^{-3}\right)$ & $0.488 \pm 0.010 a$ & $0.530 \pm 0.010 b$ & $0.561 \pm 0.010 c$ & 0.001 & 0.001 \\
\hline Volume to $A_{\mathrm{T}}$ ratio $\left(V / A_{\mathrm{T}}, \mathrm{mm}\right)$ & $0.184 \pm 0.006 a$ & $0.176 \pm 0.005 a$ & $0.177 \pm 0.005 a$ & ns. & 0.001 \\
\hline Length $(\mathrm{mm})$ & $52.3 \pm 1.5 a$ & $51.8 \pm 1.5 a$ & $54.0 \pm 1.8 a$ & ns. & 0.001 \\
\hline Width (mm) & $1.203 \pm 0.044 a$ & $1.22 \pm 0.05 a$ & $1.136 \pm 0.040 a$ & ns. & 0.001 \\
\hline Thickness (mm) & $0.603 \pm 0.016 a$ & $0.614 \pm 0.026 a$ & $0.589 \pm 0.015 a$ & ns. & 0.001 \\
\hline Nitrogen content $(\%)$ & $1.531 \pm 0.023 a$ & $1.479 \pm 0.032 a$ & $1.518 \pm 0.046 a$ & ns. & 0.01 \\
\hline Carbon content $(\%)$ & $48.17 \pm 0.27 a$ & $48.75 \pm 0.21 b$ & $48.83 \pm 0.23 b$ & 0.01 & 0.02 \\
\hline
\end{tabular}

B. Infertile site

\begin{tabular}{|c|c|c|c|c|c|c|c|}
\hline \multirow[b]{2}{*}{ Variable } & \multicolumn{5}{|c|}{ Needle age } & \multicolumn{2}{|c|}{$P$} \\
\hline & $1-\mathrm{yr}$ & $2-\mathrm{yr}$ & $3-y r$ & $4-y r$ & $5-\mathrm{yr}$ & $\overline{\text { Age }}$ & $Q_{\text {int }}$ \\
\hline Total needle area $\left(A_{\mathrm{T}}, \mathrm{mm}^{2}\right)$ & $71.5 \pm 4.1 a$ & $68.8 \pm 4.1 a$ & $72.3 \pm 3.4 a$ & $58.5 \pm 6.4 a$ & $83.4 \pm 9.6 a$ & ns. & ns. \\
\hline$A_{\mathrm{T}}$ to projected area ratio $\left(A_{\mathrm{T}} / A_{\mathrm{P}}\right)$ & $2.541 \pm 0.008 a$ & $2.532 \pm 0.009 a$ & $2.575 \pm 0.047 a$ & $2.490 \pm 0.022 a$ & $2.497 \pm 0.023 a$ & ns. & ns. \\
\hline Dry mass per $A_{\mathrm{T}}\left(\mathrm{g} \mathrm{m}^{-2}\right)$ & $93.7 \pm 1.5 a$ & $103.3 \pm 1.6 b$ & $114.5 \pm 1.7 c$ & $110.7 \pm 5.1 b c$ & $126.6 \pm 2.3 c$ & 0.001 & 0.001 \\
\hline Density $\left(\mathrm{g} \mathrm{cm}^{-3}\right)$ & $0.611 \pm 0.009 a$ & $0.688 \pm 0.015 b$ & $0.730 \pm 0.014 b$ & $0.727 \pm 0.031 b$ & $0.778 \pm 0.023 b$ & 0.001 & 0.001 \\
\hline Volume to $A_{\mathrm{T}}$ ratio $\left(V / A_{\mathrm{T}}, \mathrm{mm}\right)$ & $0.1539 \pm 0.0021 a$ & $0.1514 \pm 0.0024 a$ & $0.1579 \pm 0.0023 a$ & $0.1543 \pm 0.0043 a$ & $0.163 \pm 0.008 a$ & ns. & 0.005 \\
\hline Length (mm) & $25.5 \pm 1.1 a$ & $24.6 \pm 1.1 a$ & $25.8 \pm 1.0 a$ & $21.2 \pm 2.1 a$ & $28.8 \pm 2.3 a$ & ns. & ns. \\
\hline Width (mm) & $1.073 \pm 0.021 a$ & $1.074 \pm 0.024 a$ & $1.089 \pm 0.016 a$ & $1.102 \pm 0.021 a$ & $1.153 \pm 0.039 a$ & ns. & 0.01 \\
\hline Thickness (mm) & $0.510 \pm 0.009 a$ & $0.503 \pm 0.011 a$ & $0.510 \pm 0.008 a$ & $0.491 \pm 0.017 a$ & $0.521 \pm 0.027 a$ & ns. & 0.005 \\
\hline Nitrogen content $(\%)$ & $0.866 \pm 0.022 a$ & $0.993 \pm 0.032 b$ & $0.896 \pm 0.037 a b$ & $\mathrm{nd}^{3}$ & nd. & 0.02 & ns. \\
\hline Carbon content $(\%)$ & $49.25 \pm 0.14 a$ & $50.13 \pm 0.10 b$ & $50.39 \pm 0.10 c$ & nd. & nd. & 0.001 & ns. \\
\hline
\end{tabular}

${ }^{1}$ Means with the same letter are not significantly different $(P>0.05)$. The means were compared either by co-variation analyses when $Q_{\text {int }}$ significantly correlated with the specific foliar characteristic or by one way analyses of variance when $Q_{\text {int }}$ was insignificant in the former analysis. The interaction term, age x $Q_{\text {int }}$, was insignificant in all cases $(P>0.2)$. Thus, the co-variation analyses only included the factor and the covariate (common slope model). After the analysis of variance, Bonferroni test was employed to separate the significantly different means; ${ }^{2} \mathrm{~ns} .:$ not significant; 3 nd.: not determined.

observed in conifers $[12,23,38,44,79,88]$. As our study indicates, this relationship is strongly affected by site fertility (figure 3). Average shoot length responded to irradiance in the fertile site, but did not depend on irradiance in the infertile site (figure $3 B$ ). The fact that shoot length was positively correlated with needle nitrogen (figure $3 A$ ) and phosphorus contents in the infertile site provides conclusive evidence that the growth was chiefly limited by nutrients rather than by light in this site.

In conifers, absolute rates of lateral canopy extension respond to irradiance similarly to height growth $[12,88]$. Yet, the height growth increment generally exceeds the lateral growth such that the ratio of lateral to vertical growth may be negatively related to irradiance $[12,15,88]$. A relatively larger increase of vertical relative to horizontal growth with increasing irradiance is a major factor leading to various crown geometries - flat in low irradiance vs. conical in high irradiance. Thus, the arrested height growth may provide an explanation for the flat crown shape in the open environments in the infertile site.

The distributions of shoot length in forest trees are generally peaked and asymmetric with a greater number of short than long shoots [77] as was also observed in $P$. sylvestris in the fertile site (figure $4 A, B$ ). Similarly to previous observations in conifers $[80,90]$, the number of short shoots relative to long shoots increased progressively with increasing light availability in the fertile site (figure $4 A, B$ ) indicating a stronger apical control at higher irradiance. Although shoots branched more frequently at higher irradiance in the fertile site (figure $4 C$ ), stronger apical control permitted preferential resource investment in height growth. In contrast, apical control was released in the infertile site, where the shoot 


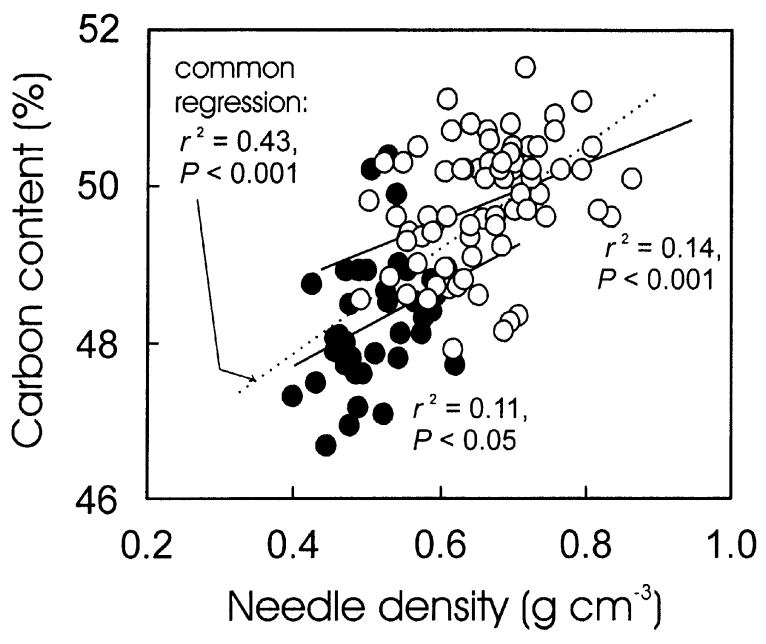

Figure 9. Needle carbon contents $\left(C_{\mathrm{M}}\right)$ in relation to needle density $(D)$ in the fertile (filled circles) and the infertile site (open circles). All measured needle-age classes (table I) were pooled. The slopes were not significantly different between the sites (separate slope ANCOVA, $P>0.3)$, but the intercepts were different $(P<0.001$, common slope analysis). To better demonstrate the trend, a common regression was also fitted through all data.

distributions were essentially normal (figure $4 A, B$ ), and the competition for resources by many independent growth points resulted in primarily horizontal canopy extension. There is evidence that hormones are involved in the apical control, but the mechanisms of hormone action are still unknown $[13,90]$. Yet, there are conclusive data indicating that strong sinks for assimilate, either in the leader shoot or in the stem and roots, are required for effective apical control [89]. Given that growth was limited by nutrients in the infertile site, low sink activities may provide a mechanistic explanation for lower apical control of shoot growth in the infertile site.

\subsection{Branching morphology}

Bifurcation ratio $\left(R_{\mathrm{b}}\right.$, Eq. (2)) is an important branch parameter $[22,40]$ that may strongly affect the shoot density in the canopy [11], and thereby the aggregation of the leaf area. Although there exist non-plastic species with bifurcation ratios independent of long-term light availability [11, 61, 65, 87], $R_{\mathrm{b}}$ is generally positively related to $Q_{\text {int }}[7,11,41,65,76$, 77]. More frequent branching at higher irradiance results in greater shoot number per unit crown volume and for greater photosynthesizing leaf area. Leaf area density generally increases with increasing light availability in the canopy [74], possibly because of the positive scaling of $R_{\mathrm{b}}$ with irradiance.

The dependence of $R_{\mathrm{b}}$ on $Q_{\text {int }}$ in $P$. sylvestris in the fertile site indicates that it is a plastic species, but also that it requires high nutrient availabilities for maximum branching intensity and foliar area development. Although the high light environment favours conical crowns with multiple leaf layers (Introduction), $P$. sylvestris formed such crowns only in the high nutrient availability site. In the infertile site, branching morphology was not plastically modified in response to irradiance, and reduced shoot length growth, low rate of branching (figures 3 and $4 C$ ) and more horizontal branch inclination angles (personal observations) led to flat crowns with a few needle layers at all irradiances in this site. Because the flat crowns allow maximization of exposed needle area, such a foliar arrangement is particularly apt to low understory irradiances. Yet, the minimization of self-shading is not necessarily advantageous in high irradiance, because it increases the risk of photoinhibitory damage [64]. Given that the photosynthetic capacities were strongly reduced in the infertile relative to the fertile site [55], the probability for photoinhibition at a common incident quantum flux density ([62] for a review) was greater in the infertile than in the fertile site. Thus, we conclude that nutrient availability strongly curbed the morphological adjustment of crown shape and that the resulting crown architectures were not optimal for the specific environmental conditions.

Previously, the correlation between shoot length and bifurcation ratio has been used to model the canopy architecture in $P$. sylvestris $[34,36]$. However, as our study demonstrates (figure 5), this relationship is considerably weaker in nutrient-limited environments where the shoots of the same length branch more frequently than the branches in the fertile site.

\subsection{Dry matter partitioning between stems and foliage within the branch}

Partitioning of shoot biomass between needles and shoot axes may be an additional determinant of foliar area in the tree. Conifers may decrease needle to shoot axis mass ratio with increasing irradiance [14, 33, 39, 44], thereby allowing more extensive needle area development at a common biomass investment in branches in low light. However, in our study, there was an increase in the fractional investment in needles with increasing $Q_{\text {int }}$ in the fertile site, and no effect of $Q_{\text {int }}$ in the other site (figure 4D). In other works, it has been observed that the fractional investment in needles was independent of irradiance [38, 56]. We cannot currently explain these contrasting patterns between the studies. However, given that conifers' branches must sustain extensive snow loads in the winter, the requirements for mechanical stability may provide a possible explanation for the larger biomass investment in support in low irradiance. The branches are more horizontal in the lower canopy of $P$. sylvestris [35, 79], and thus, have effectively longer lever arms with greater biomass requirements for mechanical support $[26,46]$.

By the same token, the circumstance that the branches were essentially horizontal in the bog, and vertical in the forest (personal observations) may be a reason for lower needle to shoot axis mass ratio in the infertile site (figure $4 D$ ). In addition, stand density was less in the infertile $\left(200\right.$ trees ha $\left.^{-1}\right)$ than in the fertile (1400 trees ha $\left.{ }^{-1}\right)$ site. According to the simulation studies, the risk of snow damage is larger in stands with lower density [63], because average wind speeds are higher in less dense stands. Thus, the evidence collectively suggests that the lower biomass investment in the needles in the infertile site may reflect greater snow loads and mechanical stress in the winter. 


\subsection{Modification of average needle age by site nutrient availability}

Decreases in shoot growth and branching in the infertile site can somewhat be compensated for by increased needle life span (figure 6). We hypothesized that the bifurcation ratio and needle longevity may be interrelated, because in species possessing leaves with a longer life span, an extensive foliar area can be formed with a lower frequency of branching. Although we did not observe such a relationship within the sites, the assumption was fulfilled for the patterns across the sites (cf. figures $4 C$ and 6 ).

We studied average needle age, and therefore, it is relevant to consider that the relationship between the average needle age calculated as the mass-weighted average (Eq. (5)) and needle longevity depends directly on shoot bifurcation ratio. This is because in a branching canopy, the mass of younger needle age classes is always progressively larger than the mass of older needle age classes, and this leads necessarily to a lower average needle age. For example, if the individual mother and daughter shoots have similar average needle mass, the total needle mass of daughter shoots is equal to $R_{\mathrm{b}}$ times the mass of needles in mother shoots. Nevertheless, the maximum needle age observed in our study was six years in the bog and four years in the forest. In addition, the needle to shoot axis dry mass ratio was significantly larger for older needle age classes in the bog as well (figure 7). Thus, we argue that modifications in average needle age (figure 6) truly mirror the changes in needle longevity.

According to the leaf life span model of Ackerly [1], the foliar life span reflects the shading patterns within the shoot. The model predicts that leaf life span increases with decreasing the rate of leaf production, because the older leaves intercept higher irradiances longer in branches with less rapid new leaf production, and accordingly, their carbon balance turns zero later than in branches with more rapid foliar production. Given that low needle growth rates were accompanied by increased average needle age in $P$. sylvestris, our results also agree with the model.

Although nitrogen and other limiting elements are retranslocated from senescing conifer foliage [17, 27, 31, 52], large quantities of nitrogen are necessary to increase the efficiency of light harvesting in shaded needles [9, 10]. Given that needles in most shaded shoot positions are the first to abscise [48], keeping high $\mathrm{N}$ contents in older, but functionally active needles may be an important acclimation response to increase the light interception efficiency in the low light environments [48]. Maintenance of high $\mathrm{N}$ contents may also be the prerequisite for high needle longevity [48]. We found that the needle nutrient contents were independent of needle age in the fertile site, and were even larger in the second- than in the currentyear needles in the infertile site (table I). Larger $\mathrm{N}$ contents in the second-year needles hint at lower rate of nutrient loss in the bog than in the forest. Reduced rate of age-related declines in needle $\mathrm{N}$ contents and thus, in the functional activity of needles in the infertile site, may be directly associated with decreased growth rates and less extensive shading in this site. Thus, the foliar nitrogen vs. age dependencies also indirectly support the argument that the shoot growth rates may exert an effective control over needle longevity.

\subsection{Morphological and chemical characteristics of needles of various age}

Apart from carbon balance arguments, needle longevity may directly depend on foliage structural characteristics that improve needle resistance to mechanical damage as well as on the speed of age-related modifications in foliage structural characteristics. There is conclusive evidence of secondary needle growth in conifers $[18,25]$. As the needles age, the number of xylem and phloem layers increases in the vascular bundles of conifer needles $[18,25]$. Possibly because of the secondary needle growth, needle thickness and width increased with increasing needle age in Picea abies [48]. However, we did not find any significant age effect on needle width and thickness (table I), and needle volume to total area ratio was also independent of age in $P$. sylvestris (figure $8 C, D$ ). Given that with increasing the number of xylem and phloem layers in the needle vascular bundles, phloem and xylem become increasingly compressed $[18,25]$, restricted expansion of vascular bundles because of lignified cell walls of the bundle sheath cells may explain away the missing age effect on needle thickness and width in the present study. Increases in needle carbon concentrations with needle age (table I) indirectly support the idea of advancing lignification with needle age. Lignin is a carbon-rich chemical (65.4\% C, calculated according to [24]), and increases in foliar lignin contents are generally accompanied by increases in $\mathrm{C}$ contents [57].

As in other conifers $[10,48]$, the explained variance in leaf structure vs. $Q_{\text {int }}$ relationships consistently decreased with increasing needle age (figure 8). However, there were no irradiance $x$ age interactions, indicating that irradiance did not influence the age-related modifications in needle structure. An increase in needle dry mass per unit area (table I, figure $8 A, B$ ) was the primary age-caused change in needle morphology. Similar changes in $M_{\mathrm{A}}$ with age have also been observed previously [27, 48, 82]. As the former [48] and current work demonstrate, changes in $M_{\mathrm{A}}$ primarily result from modifications in needle density (table I). Such adjustments in density are compatible with smaller and more tightly packed cells, greater fraction of cell walls in the leaves and greater lignification [50], and accordingly with mechanically more resistant leaves [51]. Given that the needle density was consistently larger in the infertile relative to the fertile site (table I), it is probable that changes in density may be an important driver of needle longevity.

In conclusion, we demonstrated extensive light-related plastic adjustments in crown architectural characteristics in $P$. sylvestris, but also that the plasticity strongly depended on site nutrient availability. There was evidence that the crowns developing in the infertile site were not optimal for light interception and plant performance. Although the growth was limited by nitrogen in this site, and the effective light capture was not of paramount importance for growth, the crowns with low self-shading likely led to high risk of photoinhibitory damage in high irradiance. We also found an extension in needle life span with decreasing nutrient availability. This nutrient availability related modification in needle longevity is possibly the direct consequence of altered shoot growth and within canopy shading patterns. Yet, changes in needle morphological characteristics that alter needle resistance to 
mechanical lesions may also play a role in needle longevity. From a practical perspective, the interrelationships between crown structural characteristics may be used to model the canopy architecture in $P$. sylvestris [36]. However, our study indicates that such relationships strongly depend on nutrient availability, and we conclude that site fertility controls on branching and shoot length growth must be included in the future canopy architecture models.

Acknowledgements: We thank Jack B. Fisher (Fairchild Tropical Garden, Coral Gables (Miami), FL, USA) and an anonymous reviewer for providing insightful comments on the study. We acknowledge the theoretical and technical assistance of Olevi Kull, Maarika Mäesalu, Anu Sõber (Institute of Ecology, Tallinn University of Educational Sciences). We thank Anne Jõeveer (Tõravere Meteorological Station, Estonia) for the solar radiation data during 1998 and 1999, and Kai Kimmel (Endla State Nature Reserve) for the permission to work in Endla State Nature Reserve. The Estonian Science Foundation (grants 3235, 4584), the Estonian Minister of Education (Grants 0180517s98 and 0281770Bs01), and the Bayreuther Institut für Terrestrische Ökosystemforschung (BITÖK), University of Bayreuth, Germany (BBWFT grant 0339476C) provided the financial support to the study.

\section{REFERENCES}

[1] Ackerly D., Self-shading, carbon gain and leaf dynamics: a test of alternative optimality models, Oecologia 119 (1999) 300-310.

[2] Albaugh T.J., Allen H.L., Dougherty P.M., Kress L.W., King J.S., Leaf area and above- and belowground growth responses of loblolly pine to nutrient and water additions, For. Sci. 44 (1998) 317-328.

[3] Beaudet M., Messier C., Growth and morphological responses of yellow birch, sugar maple, and beech seedlings growing under a natural light gradient, Can. J. For. Res. 28 (1998) 1007-1015.

[4] Belsley D.A., Kuh E., Welsch R.E., Regression diagnostics: identifying influential data and sources of collinearity, John Wiley \& Sons, New York, 1980.

[5] Berninger F., Mencuccini M., Nikinmaa E., Grace J., Hari P., Evaporative demand determines branchiness of Scots pine, Oecologia 102 (1995) 164-168.

[6] Bongers F., Sterck F.J., Architecture and development of rainforest trees: responses to light variation, in: Newbery D.M., Prins H.H.T., Brown N.D. (Eds.), Dynamics of tropical communities, The 37th Symposium of the British Ecological Society, London 1998, Blackwell Science, London, 1998, pp. 125-162.

[7] Boojh R., Ramakrishnan P.S., Growth strategy of trees related to successional status. I. Architecture and extension growth, For Ecol. Manage. 4 (1982) 359-374.

[8] Borchert R., Slade N.A., Bifurcation ratios and the adaptive geometry of trees, Bot. Gaz. 142 (1981) 394-401.

[9] Brooks J.R., Hinckley T.M., Sprugel D.G., Acclimation responses of mature Abies amabilis sun foliage to shading, Oecologia 100 (1994) 316-324.

[10] Brooks J.R., Sprugel D.G., Hinckley T.M., The effects of light acclimation during and after foliage expansion on photosynthesis of Abies amabilis foliage within the canopy, Oecologia 107 (1996) 21-32.

[11] Canham C.D., Growth and canopy architecture of shade-tolerant trees: response to canopy gaps, Ecology 69 (1988) 786-795.

[12] Chen H.Y.H., Klinka K., Kayahara G.J., Effects of light on growth, crown architecture, and specific leaf area for naturally established Pinus contorta var. latifolia and Pseudotsuga menziesii var. glauca saplings, Can. J. For. Res. 26 (1996) 1149-1157.

[13] Cline M.G., The role of hormones in apical dominance: new approaches to an old problem in plant development, Physiol. Plant 90 (1994) 230-237.
[14] Cregg B.M., Teskey O., Dougherty P.M., Effect of shade stress on growth, morphology, and carbon dynamics of loblolly pine branches, Trees 7 (1993) 208-213.

[15] Duchesneau R., Lesage I., Messier C., Morin H., Effects of light and intraspecific competition on growth and crown morphology of two size classes of understory balsam fir saplings, For. Ecol. Manage. 140 (2001) 215-225.

[16] Ellenberg H., Weber H.E., Düll R., Wirth V., Werner W., Paulißen D., Zeigerwerte von Pflanzen in Mitteleuropa, Scripta Geobotanica, Verlag Erich Goltze KG, Göttingen, 1991.

[17] Everett R.L., Thran D.F., Nutrient dynamics in singleleaf pinyon (Pinus monophylla Torr \& Frem.) needles, Tree Physiol. 10 (1992) $59-68$.

[18] Ewers F.W., Secondary growth in needle leaves of Pinus longaeva (bristlecone pine) and other conifers: quantitative data, Amer. J. Bot. 69 (1982) 1552-1559.

[19] Fisher J.B., Honda H., Branch geometry and effective leaf area: a study of Terminalia-branching pattern. I. Theoretical trees, Amer. J. Bot. 66 (1979) 633-644.

[20] Ford E.D., Branching, crown structure and the control of timber production, in: Cannell M.G.R., Jackson J.E. (Eds.), Attributes of trees as crop plants, Institute of Terrestrial Ecology (Natural Environment Research Council), Monks Wood Experimental Station, Abbots Ripton, Huntigdon, 1985, pp. 228-252.

[21] Ford E.D., The control of tree structure and productivity through the interaction of morphological development and physiological processes, Int. J. Plant Sci. 153 (1992) S147-S162.

[22] Ford E.D., Avery A., Ford R., Simulation of branch growth in the Pinaceae: interactions of morphology, phenology, foliage productivity, and the requirement for structural support, on the export of carbon, J. Theor. Biol. 146 (1990) 15-36.

[23] Ford E.D., Deans J.D., Milne R., Shoot extension in Picea sitchensis. I. Seasonal variation within a forest canopy, Ann. Bot. 60 (1987) 531-542.

[24] Freudenberg K., Lignin: its constitution and formation from p-hydroxycinnamyl alcohols, Science 148 (1965) 595-600.

[25] Gilmore D.W., Seymour R.S., Halteman W.A., Greenwood M.S., Canopy dynamics and the morphological development of Abies balsamea: effects of foliage age on specific leaf area and secondary vascular development, Tree Physiol. 15 (1995) 47-55.

[26] Givnish T.J., Adaptation to sun and shade: a whole-plant perspective, Aust. J. Plant Physiol. 15 (1988) 63-92.

[27] Greenway K.J., Macdonald S.E., Lieffers V.J., Is long-lived foliage in Picea mariana an adaptation to nutrient-poor conditions?, Oecologia 91 (1992) 184-191.

[28] Grimshaw H.M., Allen S.E., Parkinson J.A., Nutrient elements, in: Allen S.E. (Ed.), Chemical analysis of ecological materials, Blackwell Scientific Publications, Oxford, 1989, pp. 81-159.

[29] Hånell B., Postdrainage forest productivity of peatlands in Sweden, Can. J. For. Res. 18 (1988) 1443-1456.

[30] Helmisaari H.-S., Temporal variation in nutrient concentrations of Pinus sylvestris needles, Scand. J. Forest Res. 5 (1990) 177-193.

[31] Helmisaari H.-S., Nutrient retranslocation within the foliage of Pinus sylvestris, Tree Physiol. 10 (1992) 45-58.

[32] Kaitaniemi P., Neuvonen S., Nyyssönen T., Effects of cumulative defoliations on growth, reproduction, and insect resistance in mountain birch, Ecology 80 (1999) 524-532.

[33] Kellomäki S., Effect of the within-stand light conditions on the share of stem, branch and needle growth in a twenty-year-old Scots pine stand, Silva Fenn. 15 (1981) 130-139.

[34] Kellomäki S., Ikonen V.P., Peltola H., Kolström T., Modelling the structural growth of Scots pine with implications for wood quality, Ecol. Modelling 122 (1999) 117-134.

[35] Kellomäki S., Oker-Blom P., Canopy structure and light climate in a young Scots pine stand, Silva Fenn. 17 (1983) 1-21.

[36] Kellomäki S., Strandman H., A model for the structural growth of young Scots pine crowns based on light interception by shoots, Ecol. Modelling 80 (1995) 237-250.

[37] Kikuzawa K., Leaf survivals of tree species in deciduous broadleaved forests, Pl. Sp. Biol. 3 (1988) 67-76. 
[38] King D.A., Branch growth and biomass allocation in Abies amabilis saplings in contrasting light environments, Tree Physiol. 17 (1997) 251-258.

[39] Kohyama T., Growth pattern of Abies mariesii saplings under conditions of open-growth and suppression, Bot. Mag. Tokyo 93 (1980) 13-24.

[40] Küppers M., Canopy gaps: competitive light interception and economic space filling - a matter of whole-plant allocation, in Caldwell M.M., Pearcy R.W. (Eds.), Exploitation of environmental heterogeneity by plants. Ecophysiological processes above- and belowground, Physiological ecology. A series of monographs, texts, and treatises, Academic Press, San Diego, 1994, pp. 111-144.

[41] Kull O., Broadmeadow M., Kruijt B., Meir P., Light distribution and foliage structure in an oak canopy, Trees 14 (1999) 55-64.

[42] Linder S., Responses to water and nutrients in coniferous ecosystems, in: Schulze E.-D., Zwölfer H. (Eds.), Potentials and limitations of ecosystem analysis, Ecological Studies, SpringerVerlag, Berlin, 1987, pp. 180-202.

[43] Linder S., Foliar analysis for detecting and correcting nutrient imbalances in Norway spruce, Ecological Bulletins 44 (1995) 178-190.

[44] Mailly D., Kimmins J.P., Growth of Pseudotsuga menziesii and Tsuga heterophylla seedlings along a light gradient: resource allocation and morphological acclimation, Can. J. Bot. 75 (1997) 1424-1435.

[45] Miyaji K.-I., Da Silva W.S., Alvim P.D., Longevity of leaves of a tropical tree, Theobroma cacao, grown under shading, in relation to position within the canopy and time of emergence, New Phytol. 135 (1997) 445-454.

[46] Morgan J., Cannell M.G.R., Support costs of different branch designs: effects of position, number, angle and deflection of laterals, Tree Physiol. 4 (1988) 303-313.

[47] Murthy R., Dougherty P.M., Effect of carbon dioxide, fertilization and irrigation on loblolly pine branch morphology, Trees 11 (1997) 485-493.

[48] Niinemets Ü., Acclimation to low irradiance in Picea abies: influences of past and present light climate on foliage structure and function, Tree Physiol. 17 (1997) 723-732.

[49] Niinemets Ü., Distribution patterns of foliar carbon and nitrogen as affected by tree dimensions and relative light conditions in the canopy of Picea abies, Trees 11 (1997) 144-154.

[50] Niinemets Ü., Research review. Components of leaf dry mass per area - thickness and density - alter leaf photosynthetic capacity in reverse directions in woody plants, New Phytol. 144 (1999) 35-47.

[51] Niinemets Ü., Climatic controls of leaf dry mass per area, density, and thickness in trees and shrubs at the global scale, Ecology 82 (2001) 453-469.

[52] Niinemets Ü., Stomatal conductance alone does not explain the decline in foliar photosynthetic rates with increasing tree age and size in Picea abies and Pinus sylvestris, Tree Physiol. 22 (2002) $515-535$.

[53] Niinemets Ü., Bilger W., Kull O., Tenhunen J.D., Acclimation to high irradiance in temperate deciduous trees in the field: changes in xanthophyll cycle pool size and in photosynthetic capacity along a canopy light gradient, Plant Cell Environ. 21 (1998) 1205-1218.

[54] Niinemets Ü., Cescatti A., Lukjanova A., Tobias M., Truus L., Modification of light-acclimation of Pinus sylvestris shoot architecture by site fertility, Agric. For. Meteorol. 111 (2002) 121-140.

[55] Niinemets Ü., Ellsworth D.S., Lukjanova A., Tobias M., Site fertility and the morphological and photosynthetic acclimation of Pinus sylvestris needles to light, Tree Physiol. 21 (2001) $1231-1244$

[56] Niinemets Ü., Kull O., Effects of light availability and tree size on the architecture of assimilative surface in the canopy of Picea abies: variation in shoot structure, Tree Physiol. 15 (1995) 791-798.

[57] Niinemets Ü., Kull O., Tenhunen J.D., Variability in leaf morphology and chemical composition as a function of canopy light environment in co-existing trees, Int. J. Plant Sci. 160 (1999) 837-848.

[58] Nikinmaa E., Geographical aspects of the growth of Scots pine: results of simulations, in: Hari P., Ross J., Mecke M. (Eds.), Production process of Scots pine: geographical variation and models, Acta Forestalia Fennica, Finnish Society of Forest Science - Finnish Forest Research Institute, Helsinki, 1996, pp. 97-119.

[59] Norgren O., Growth analysis of Scots pine and lodgepole pine seedlings, For. Ecol. Manage. 86 (1996) 15-26.

[60] O'Connell B.M., Kelty M.J., Crown architecture of understory and open-grown white pine (Pinus strobus L.) saplings, Tree Physiol. 14 (1994) 89-102.

[61] Oohata S., Shidei T., Studies on the branching structure of trees. I Bifurcation ratio of trees in Horton's law, Jap. J. Ecol. 14 (1971) 97-105.

[62] Osmond C.B., Anderson J.M., Ball M.C., Egerton J.G., Compromising efficiency: the molecular ecology of light-resource utilization in plants, in: Press M.C., Scholes J.D., Barker M.G. (Eds.), Physiological plant ecology. The 39th Symposium of the British Ecological Society held at the University of York, 7-9 September 1998, Blackwell Science, Oxford, 1999, pp. 1-24.

[63] Päätalo M.-L., Peltola H., Kellomäki S., Modelling the risk of snow damage to forests under short-term snow loading, For. Ecol. Manage. 116 (1999) 51-70.

[64] Pearcy R.W., Valladares F., Resource acquisition by plants: the role of crown architecture, in: Press M.C., Scholes J.D., Barker M.G. (Eds.), Physiological plant ecology, Blackwell Science - MPG Books Ltd., Cornwall, 1999, pp. 45-66.

[65] Pickett S.T.A., Kempf J.S., Branching patterns in forest shrubs and understory trees in relation to habitat, New Phytol. 86 (1980) 219-228.

[66] Reich P.B., Koike T., Gower S.T., Schoettle A.W., Causes and consequences of variation in conifer leaf life-span, in: Smith W.K., Hinckley T.M. (Eds.), Ecophysiology of coniferous forests, Physiological ecology. A series of monographs, texts, and treatises, Academic Press, Inc., San Diego, 1995, pp. 225-254.

[67] Roberntz P., Effects of long-term $\mathrm{CO}_{2}$ enrichment and nutrient availability in Norway spruce. I. Phenology and morphology of branches, Trees 13 (1999) 188-198.

[68] Room P.M., Maillette L., Hanan J.S., Module and metamer dynamics and virtual plants, Adv. Ecol. Res. 25 (1994) 105-157.

[69] Ruohomäki K., Haukioja E., Repka S., Lehtilä K., Leaf value: effects of damage to individual leaves on growth and reproduction of mountain birch shoots, Ecology 78 (1997) 2105-2117.

[70] Sampson D.A., Allen H.L., Light attenuation in a 14-year-old loblolly pine stand as influenced by fertilization and irrigation, Trees 13 (1998) 80-87.

[71] SAS Institute Inc., SAS/STAT User's guide, Version 6, SAS Institute Inc., Cary, NC, 1990.

[72] Schoettle A.W., Potential effect of premature needle loss on the foliar biomass and nutrient retention of lodgepole pine, in: Olson R.K., Lefohn A.S. (Eds.), Transactions of air pollution on western forests, Air \& Waste Management Association, Anheim, 1989, pp. 443-454.

[73] Sionit N., Response of soybean to two levels of mineral nutrition in $\mathrm{CO}_{2}$-enriched atmosphere, Crop Sci. 23 (1983) 329-333.

[74] Sorrensen-Cothern K.A., Ford E.D., Sprugel D.G., A model of competition incorporating plasticity through modular foliage and crown development, Ecol. Monogr. 63 (1993) 277-304.

[75] Sprugel D.G., Hinckley T.M., Schaap W., The theory and practice of branch autonomy, Annu. Rev. Ecol. Syst. 22 (1991) 309-334.

[76] Steingraeber D.A., Phenotypic plasticity of branching pattern in sugar maple (Acer saccharum), Amer. J. Bot. 69 (1982) 638-640.

[77] Steingraeber D.A., Kascht L.J., Frank D.H., Variation of shoot morphology and bifurcation ratio in sugar maple (Acer saccharum) saplings, Amer. J. Bot. 66 (1979) 441-445.

[78] Stenberg P., Kuuluvainen T., Kellomäki S., Grace J.C., Jokela E.J., Gholz H.L., Crown structure, light interception and productivity of pine trees and stands, in: Gholz H.L., Linder S., McMurtrie R.E. (Eds.), Environmental constraints on the structure and productivity 
of pine forest ecosystems: a comparative analysis, Ecological Bulletins, Munksgaard International Booksellers and Publishers, Copenhagen, 1994, pp. 20-34.

[79] Stenberg P., Smolander H., Kellomäki S., Description of crown structure for light interception models: angular and spatial distribution of shoots in young Scots pine, in: Linder S., Kellomäki S. (Eds.), Management of structure and productivity of boreal and subalpine forests, Studia Forestalia Suecica, 1993, pp. 43-50.

[80] Stoll P., Schmid B., Plant foraging and dynamic competition between branches of Pinus sylvestris in contrasting light environments, J. Ecol. 86 (1998) 934-945.

[81] Takenaka A., Shoot growth responses to light microenvironment and correlative inhibition in tree seedlings under a forest canopy, Tree Physiol. 20 (2000) 987-991.

[82] Tucker G.F., Emmingham W.H., Morphological changes in leaves of residual western hemlock after clear and shelterwood cutting, For. Sci. 23 (1977) 195-203.

[83] Turner I.M., Gong W.K., Ong J.E., Bujang J.S., Kohyama T., The architecture and allometry of mangrove saplings, Funct. Ecol. 9 (1995) 205-212.
[84] Valladares F., Architecture, ecology, and evolution of plant crowns, in: Pugnaire F.I., Valladares F. (Eds.), Handbook of functional plant ecology, Marcel Dekker, Inc., New York, 1999 pp. 121-194.

[85] Veber K., Vegetation history of the Endla mire system, in: Kumari E. (Ed.), Estonian wetlands and their life, Estonian contributions to the IBP, Valgus, Tallinn, 1974, pp. 160-182.

[86] Vose J.M., Allen H.L., Leaf area, stemwood growth, and nutrition relationships in loblolly pine, For. Sci. 34 (1988) 547-563.

[87] Whitney G.G., The bifurcation ratio as an indicator of adaptive strategy in woody plant species, Bull. Torrey Bot. Club 103 (1976) $67-72$.

[88] Williams H., Messier C., Kneeshaw D.D., Effects of light availability and sapling size on the growth and crown morphology of understory Douglas-fir and lodgepole pine, Can. J. For. Res. 29 (1999) 222-231.

[89] Wilson B.F., Branches versus stems in woody plants: control of branch diamater growth and angle, Can. J. Bot. 76 (1998) 1852-1856.

[90] Wilson B.F., Apical control of branch growth and angle in woody plants, Amer. J. Bot. 87 (2000) 601-607. 